\title{
PENINGKATAN PENGETAHUAN PENCEGAHAN INFEKSI VIRUS CORONA PADA IBU MENYUSUI MELALUI MEDIA VIDEO DAN PEMBAGIAN APD PADA IBU MENYUSUI DI WILAYAH KERJA PUSKESMAS WOSI KABUPATEN MANOKWARI
}

\author{
Bahrah $^{1^{*}}$, Dwi Iryani ${ }^{2}$ \\ 1-2Poltekkes Kemenkes Sorong \\ Email Korespondensi: rha_poe@yahoo.co.id \\ Disubmit: 27 Juli 2021 Diterima: 09 Agustus $2021 \quad$ Diterbitkan: 05 Februari 2022 \\ DOI: https://doi.org/10.33024/jkpm.v5i2.4723
}

\begin{abstract}
ABSTRAK
Bayi baru lahir rentan terhadap infeksi virus COVID-19 dikarenakan belum sempurna fungsi imunitasnya. Berdasarkan hasil survey pendahuluan yang dilakukan melalui wawancara kepada salah satu Bidan di Puskesmas Wosi Kabupaten Manokwari secara daring, bahwa saat ini tidak adanya pelayanan pada ibu nifas atau ibu menyusui. Berdasarkan hasil wawancara hingga bulan Maret tahun 2020 jumlah ibu nifas atau ibu menyusui sebanyak 53 orang ibu. Tujuan dari pengabdian ini adalah meningkatkan pemahaman ibu menyusui tentang pencegahan covid 19 pada ibu menyusui dan penggunaan APD pada ibu menyusui. Metode dalam pengabdian ini adalah dengan melakukan penyuluhan menggunakan media bantu video dan melakukan pendampingan. Sasaran dalam pengabdian ini adalah ibu menyusui yang ada di PKM Wosi. Kegiatan pengabdian ini dilakukan selama 1 bulan dengan menggunakan media kuisioner dan video cara pencegahan covid 19 pada ibu menyusui. Berdasarkan evaluasi yang telah dilakukan hasil pengabdian bahwa terjadi peningkatan pengetahuan ibu menyusui setelah diberikan penyuluhan menggunakan media video selama 14 hari, dimana terjadi peningkatan skor pengetahuan sebelum diberikan media video dengan rata-rata nilai pengetahuan 4,5 sedangkan setelah diberikan media video selama 14 hari terjadi peningkatan pengetahuan dengan nilai rata- rata pengetahuan 9,1. Kesimpulan bahwa media bantu video dapat meningkatkan pengetahuan atau pemahaman ibu menyusui tentang pencegahan covid 19 pada ibu menyusui dan penggunaan APD. Diharapkan bidan untuk selalu memberikan informasi terkait dengan pencegahan covid 19 pada ibu menyusui dan kepada ibu menyusui agar tetap memperhatikan protokol kesehatan sebagai kelompok berisiko yang memiliki bayi sebagai bentuk pencegahan terhadap covid 19 .
\end{abstract}

Kata Kunci: Covid-19, Media Video, Peningkatan Pengetahuan

\section{ABSTRACT}

Newborns are susceptible to infection with the COVID-19 virus because their immune function is not yet perfect. Based on the results of a preliminary survey conducted through online interviews with one of the midwives at the Wosi Health Center, Manokwari Regency, that currently there is no service for postpartum or breastfeeding mothers. Based on the results of interviews until March 2020, the number of postpartum mothers or breastfeeding mothers was 53 mothers. The purpose of this service is to increase the understanding of 
breastfeeding mothers about the prevention of covid 19 in nursing mothers and the use of PPE for breastfeeding mothers. The method in this service is to conduct counseling using video media and provide assistance. The target in this service is nursing mothers in Wosi Health Center. This service activity was carried out for 1 month using questionnaires and videos on how to prevent covid 19 in breastfeeding mothers. Based on the evaluation that has been carried out, the results of the service show that there is an increase in knowledge of breastfeeding mothers after being given counseling using video media for 14 days, where there is an increase in knowledge scores before being given video media with an average knowledge value of 4.5 while after being given video media for 14 days it occurs. increased knowledge with an average value of knowledge 9.1. The conclusion is that video aids can increase knowledge or understanding of breastfeeding mothers about the prevention of covid 19 in breastfeeding mothers and the use of PPE. Midwives are expected to always provide information related to the prevention of covid 19 to breastfeeding mothers and to nursing mothers to continue to pay attention to health protocols as a risk group having babies as a form of prevention against covid 19.

Keywords: Covid-19, Video Media, Knowledge Improvement

\section{PENDAHULUAN}

Dalam situasi normal, kematian ibu dan kematian neonatal di Indonesia masih menjadi tantangan besar, apalagi pada saat situasi bencana. Saat ini, Indonesia sedang menghadapi bencana nasional non alam COVID-19 sehingga pelayanan kesehatan maternal dan neonatal menjadi salah satu layanan yang terkena dampak baik secara akses maupun kualitas. Dikhawatirkan, hal ini menyebabkan adanya peningkatan morbiditas dan mortalitas ibu dan bayi baru lahir (Pedoman Bagi Ibu Hamil, Bersalin, Nifas dan BBL, 2020). Dalam situasi pandemi COVID-19 ini, banyak pembatasan hampir ke semua layanan rutin termasuk pelayanan kesehatan maternal dan neonatal. Seperti ibu hamil menjadi enggan ke puskesmas atau fasiltas pelayanan kesehatan lainnya karena takut tertular, adanya anjuran menunda pemeriksaan kehamilan dan kelas ibu hamil, serta adanya ketidaksiapan layanan dari segi tenaga dan sarana prasarana termasuk Alat Pelindung Diri (Pedoman Bagi Ibu Hamil, Bersalin, Nifas dan BBL, 2020).

Ibu hamil atau menyusui akan kemungkinan terjangkit Coronavirus (COVID-19) dan dampaknya terhadap kesehatan bayi. Seperti yang mungkin pernah Ibu dengar atau baca, bahwa wanita hamil lebih mungkin tertular influenza (disebabkan oleh kelas virus lain) dan tertular infeksi yang disebabkan oleh virus dari keluarga yang sama dengan Coronavirus (COVID-19). Dengan demikian, Ibu harus tetap waspada dan mengambil semua tindakan pencegahan selama kehamilan untuk meminimalisirkan resiko. Beberapa penelitian terbaru menunjukkan bahwa virus tersebut tidak masuk ke dalam plasenta atau cairan ketuban. Jadi semua bayi yang lahir dengan sehat walaupun sang Ibu terinfeksi. Namun, walaupun begitu melakukan pencegahan seperti menjaga kebersihan adalah tindakan terbaik untuk saat ini (Chen, 2020). 
Studi yang telah dilakukan tidak menemukan jejak virus dalam ASI Ibu yang telah terinfeksi. Artinya, untuk saat ini, semuanya menunjukkan bahwa Coronavirus (COVID-19) tidak menyebar saat sedang menyusui. Berbagai ahli kesehatan pun setuju bahwa jika Ibu terinfeksi, terus menyusui si kecil adalah keputusan terbaik. Karena ASI adalah makanan yang paling ideal untuk si kecil, yang memiliki semua kandungan nutrisi penting untuk menjaga sistem imunitas serta baik dalam perkembangan fisik, mental dan juga membangun ikatan emosional si kecil dengan Ibu. Dan tidak hanya itu, jika Ibu terinfeksi, tubuh Ibu akan membuat satu set antibodi spesifik yang akan masuk ke dalam ASI untuk melindungi si kecil dari virus tersebut (Chen, 2020).

Namun, Ibu harus ingat bahkan jika si kecil memiliki perlindungan tambahan dari ASI, jika terinfeksi, Ibu tetap harus melindunginya dari bersin atau batuk, serta cuci tanganlah terlebih dahulu dengan sabun sebelum menyentuh si kecil. Lalu untuk mencegah si kecil terkena infeksi, Ibu harus menggunakan masker atau penutup mulut saat menyusui, menjaga kebersihan secara maksimal dan meminta bantuan orang lain yang sehat untuk memberikan makan pada si kecil. Ada beberapa langkah sederhana yang bisa Ibu lakukan. Yang pertama adalah untuk selalu menjaga kebersihan, seringseringlah mencuci tangan dengan sabun dan juga bersihkan lantai permukaan rumah. Lalu langkah berikutnya, jangan pernah meninggalkan rumah jika tidak ada urusan yang darurat, serta pastikan untuk menghindari tempat ramai. Dan yang terakhir, jangan lupa untuk makan secara benar dan istirahatlah dengan teratur agar dapat menjaga sistem kekebalan tubuh Ibu (Chen, 2020).

Promosi kesehatan merupakan salah satu upaya yang dapat dilakukan untuk meningkatkan pengetahuan salah satunya melalui penyuluhan. Namun berhasilnya penyuluhan kesehatan tersebut pada masyarakat tergantung pada komponenn pembelajaran. Media penyuluhan kesehatan merupakan salah satu komponen dari proses pembelajaran. Media yang menarik akan memberikan keyakinan, sehingga perubahan kognitif afeksi dan psikomotor dapat dipercepat. Audiovisual merupakan salah satu media yang menyajikan informasi atau pesan secara audio dan visual (Hidayatullah, 2017). Media penyuluhan dengan audio visual memberikan stimulus terhadap mata (penglihatan) dan telinga (pendengaran), sedangkan media cetak hanya menstimulasi indra mata (penglihatan). Mengingat pentingnya promosi kesehatan maka perlu adanya metode pembelajaran atau inovasi baru agar audiens bisa menerima pesan kesehatan dengan baik. Dalam penyuluhan kesehatan, banyak media yang digunakan untuk menunjang efektivitas penyuluhan kesehatan, media cetak seperti booklet, leaflet dan lain-lain merupakan media yang sering di gunakan, sedangkan media audio visual adalah media yang jarang digunakan dalam penyuluhan kesehatan maupun pembelajaran. Pemberian pengetahuan lebih menarik jika disampaikan dengan metode dan media yang menarik pula (Hidayatullah, 2017).

Penyuluhan dalam pengabmas ini mengunakan media audio visual berupa video kesehatan tentang pencegahan covid 19 pada ibu menyusui. Materi dalam video lebih banyak menampilkan bentuk-bentuk pencegahan covid 19 pda ibu menyusui, langkah cuci tangan yang benar dan penggunaan APD yang dibuat atau dikemas secara menarik sehingga responden tertarik 
untuk membacanya dan tidak bosan. Seperti yang diketahui bahwa masyarakat terkadang cenderung bosan apabila penyuluhan kurang menarik apalagi apabila penyuluhan dalam video tersebut membutuhkan waktu yang cukup lama untuk dibaca sehingga sudah tepat apabila video yang dibawakan dibuat dan dicari yang semenarik mungkin agar menarik perhatian responden.

\section{MASALAH}

Berdasarkan hasil survey pendahuluan yang dilakukan melalui wawancara kepada salah satu Bidan di Puskesmas Wosi Kabupaten Manokwari secara daring, bahwa saat ini tidak adanya pelayanan pada ibu nifas atau ibu menyusui, sehingga Puskesmas tidak memiliki kesempatan untuk melakukan sosialisasi atau penyuluhan tentang bahaya risiko Covid 19 pada ibu menyusui serta dilaporkan bahwa saat ibu-ibu yang melakukan kunjungan untuk imunisasi bayinya, masih ditemukan ibu-ibu yang tidak menggunakan masker dan masih belum mengetahui bahaya risiko covid 19 pada bayi. Berdasarkan hasil wawancara hingga bulan Maret tahun 2020 jumlah ibu nifas atau ibu menyusui sebanyak 53 orang ibu. Berdasarkan hasil survey pendahuluan diatas bahwa terdapat masalah pada lokasi mitra dengan sasaran ibu menyusui yang merupakan kelompok berisiko dan belum mengetahui bahya covid 19 bagi bayi dan bagaimana cara pencegahannya melalui penggunaan APD sehingga perlu adanya peningkatan pengetahuan pencegahan infeksi virus corona pada ibu menyusui melalui media Video dan Pembagian APD pada ibu menyusui di Wilayah Kerja Puskesmas Wosi Kabupaten Manokwari.

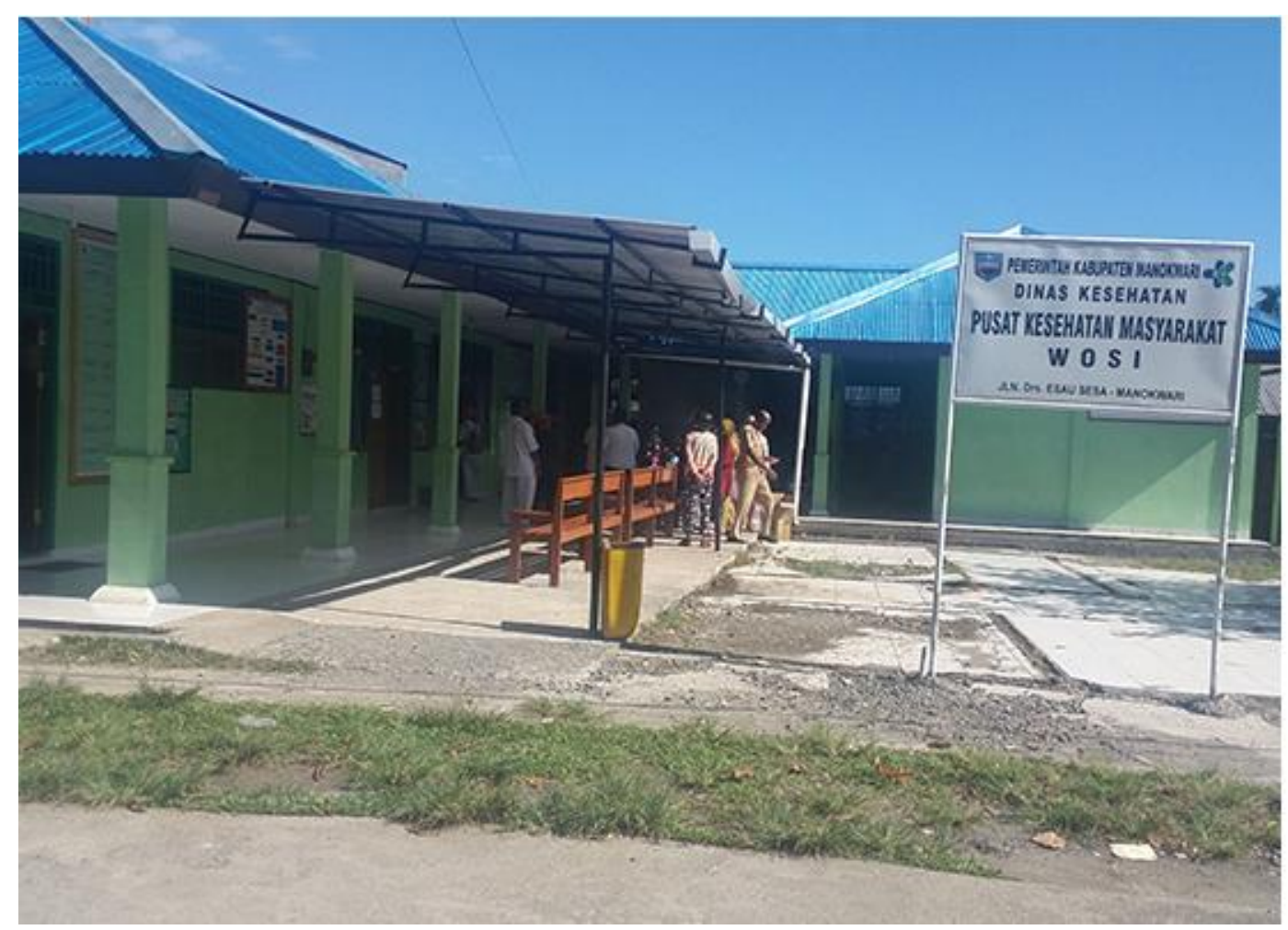

Gambar 1. Lokasi Puskesmas Wosi Kabupaten Manokwari 


\section{METODE}

a. Kerangka pemecahan masalah

Kerangka pemecahan masalah ditunjukkan pada gambar 3.1 yaitu :

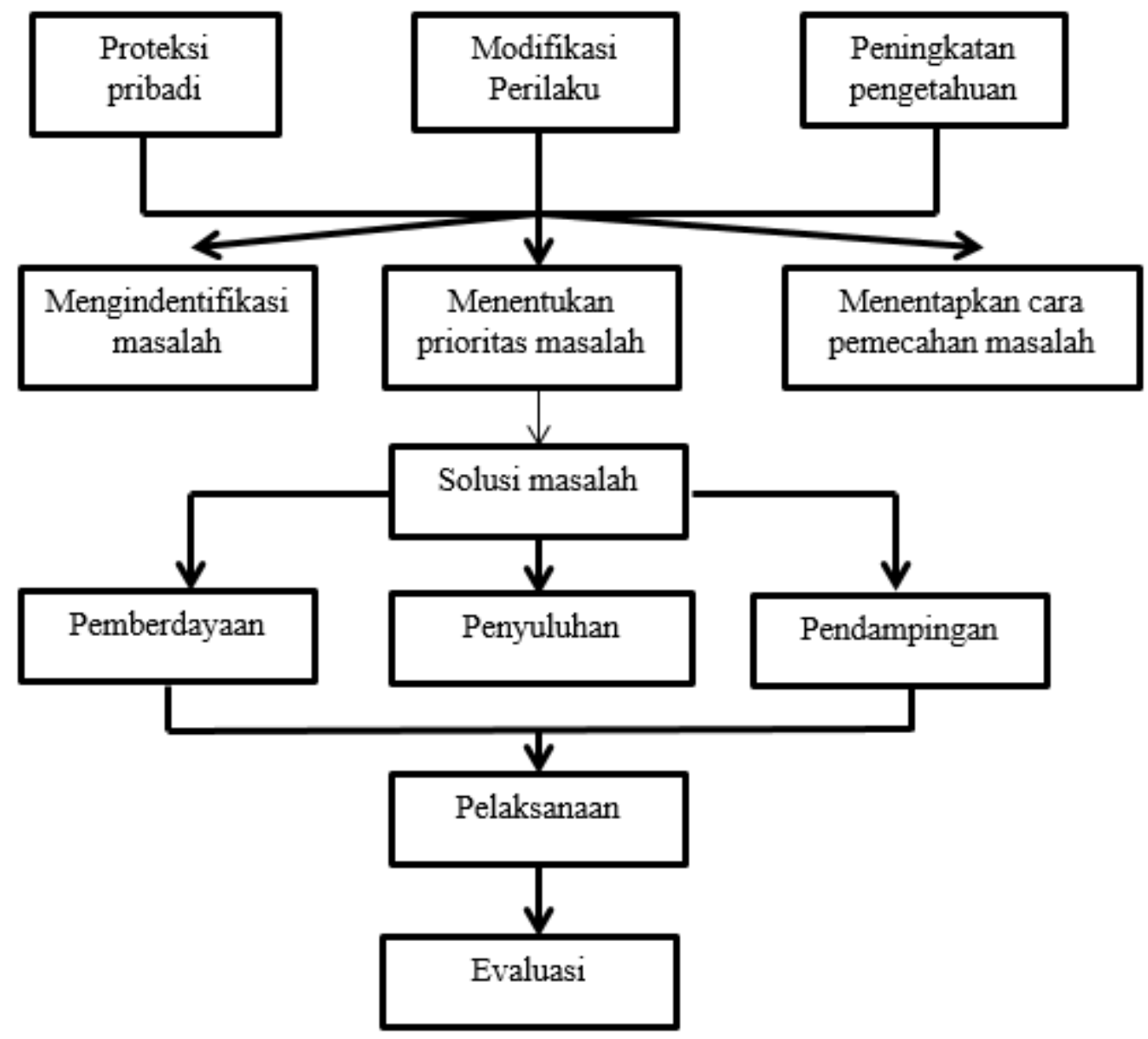

Gambar 2. Kerangka Pemecahan Masalah

b. Khalayak sasaran

Khalayak sasaran yang sesuai dan dilibatkan dalam pengabdian masyakat ini yaitu ibu menyusui yang ada di Wilayah Kerja Puskesmas Wosi Kab. Manokwari.

\section{c. Metode pengabdian}

Metode yang digunakan dalam pengabdian masyarakat ini adalah dengan cara penyuluhan, pendampingan dan pemberdayaan. Adapun metodenya yaitu melalui tahapan langkah-langkah yaitu :

1) Penyuluhan

Tim akan melakukan penyuluhan terkait dengan pencegahan covid 19 pada ibu menyusui melalui media video yang akan diberikan pada ibu menyusui yang ada di Wilayah Kerja Puskesmas Wosi. Namun sebelumnya tim akan kembali melakukan survey pendahuluan di Puskesmas, dimana tim akan menghubungi Bidan yang bertanggung jawab di Ruang KIA yang mengetahui terkait data ibu menyusui termasuk identitas lengkap responden. Setelah itu 
tim akan bersosialisasi ke bidan Puskesmas Wosi untuk melakukan pendekatan pada ibu menyusui dengan menggunakan APD Lengkap dan mengevaluasi pengetahuan ibu menyusui menggunakan kuisioner yang berisi pertanyaan dan observasi berupa :

a) Pengetahuan ibu menyusui tentang covid 19 ?

b) Bagaimana selama ini ibu menyusui melakukan pencegahan terhadap covid 19?

c) Tindakan pencegahan covid 19 di rumah yang sudah dilakukan oleh keluarga?

d) Bagaimana ibu menyusui menggunakan APD?

e) Apakah langkah penggunaan APD sudah benar?

f) Bagaimana hasil evaluasi pre test hasil observasi pengetahuan ibu menyusui tentang pencegahan covid 19 ?

Media video yang akan digunakan akan berisikan tentang pencegahan covid 19 pada ibu menyusui dan penggunaan APD. Dimana pada video akan dilakukan demonstrasi cara penggunaan APD yang benar dan termasuk cara mencuci tangan yang benar.

2) Pendampingan

Setelah melakukan pemberian video pencegahan covid 19 kepada ibu menyusui selama 1 minggu, kemudian dilakukan pendampingan kepada ibu menyusui untuk mengimplementasikan tindakan cara melakukan pencegahan covid 19 pada ibu menyusui yaitu ibu menyusui dapat mengimplementasikan bagaimana memproteksi diri penggunaan APD dan perbaikan perilaku yang benar dalam pencegahan covid 19 selama 1 minggu. Jika kemampuan pengetahuan ibu menyusui sudah meningkat dan adanya perubahan perilaku maka kemudian dilakukan post test untuk menilai tingkat kemampuan ibu menyusui dalam melakukan pencegahan sebagai bentuk evaluasi dari hasil pendampingan. Proses pendampingan akan dibantu oleh Tim atau Bidan di Puskesmas Wosi untuk membantu tim pengabdi melakukan evaluasi terhadap keberhasilan pengabdian.

d. Sarana dan Alat Yang Digunakan

Kegiatan pengabdian masyarakat ini menggunakan media kuisioner dan video cara pencegahan covid 19 pada ibu menyusui.

\section{e. Pihak Yang Terlibat}

Pihak yang terlibat dalam kegiatan pengabdian masyarakat ini adalah Dosen sabagai tim pengabdi, mahasiswa, bidan sebagai petugas kesehatan di wilayah Kerja puskesmas Wosi.

f. Keterkaitan

Kegiatan ini dilakukan oleh dosen prodi kebidanan manokwari dengan melibatkan mahasiswa dengan sasaran ibu menyusui. Dosen akan melakukan pengabdian kepada masyarakat sebagai bentuk aplikasi ilmu dan sebagai salah satu kegiatan tri dharma perguruan tinggi, serta melibatkan mahasiswa dalam kegiatan ini agar mengajarkan mahasiswa untuk lebih terpapar dengan masyarakat dan dapat mengimplementasikan teori yang telah diperoleh dimasyarakat sesuai dengan visi prodi diploma kebidanan manokwari yaitu dapat menjadi tenaga kompeten dalam memberikan asuhan pelayanan pada ibu menyusui dalam situasi pandemi covid 19. Sasaran adalah ibu menyusui yaitu dengan memberikan video pencegahan covid 19 terkait cara pencegahan, melakukan pendampingan dalam pencegahan covid 19 untuk mewujudkan pencegahan covid 19 pada ibu menyusui. 


\section{HASIL DAN PEMBAHASAN}

\section{a. Hasil Kegiatan Pengabdian Masyarakat}

1. Persiapan Materi

Materi yang disiapkan saat akan dilakukan pengabdian masyarakat adalah pesiapan materi terkait pencegahan covid 19 pada ibu menyusui dan penggunaan APD pada ibu menyusui. Materi yang akan diberikan melalui media video yang akan diberikan pada ibu menyusui. Adapun materi yang akan diberikan yaitu terkait :

a) Tindakan pencegahan umum yang dapat dilakukan oleh ibu hamil, bersalin dan nifas

b) Protokol tatalaksana bayi lahir dari Ibu terkait COVID-19 yang dikeluarkan IDAI

Persiapan materi dilakukan sesuai dengan jadwal kegiatan, sebelumnya dilakukan role play pembuatan video pencegahan covid 19 pada ibu menyusui dan penggunaan APD pada ibu menyusui, sehingga saat pelaksanaan pengabdian pengabdi terlebih dahulu akan menjelaskan isi dari video yang akan diberikan pada ibu menyusui.

2. Persiapan Sarana

Persiapan sarana yang dipersiapkan sebelum pelaksanaan kegiatan yaitu dengan menyiapkan berbagai sarana keperluan saat dilakukannya pengabdian masyarakat. Adapun persiapan sarana yaitu dilakukan oleh tim dosen pengabmas dan dibantu oleh tim mahasiswi yang terlibat dalam pengabmas ini adalah: Layar LCD, LCD, Speaker, Media video, Kabel USB, Kuisioner, Masker, Face shield, Hansanitaizer.

\section{Pelaksanaan Kegiatan}

Pelaksanaan kegiatan dalam pengabdian masyarakat ini adalah dengan cara penyuluhan menjelaskan isi dari video dan pemberian media video tentang video pencegahan covid 19 pada ibu menyusui dan penggunaan APD pada ibu menyusui. Namun sebeum pengabdi melakukan penyuluhan dan pemberian media video, sebelumnya pengabdi menyebarkan kuiioner yang harus diisi oleh ibu menyusui untuk mengetahui pengetahuan ibu menyusui tentang pencegahan covid 19 pada ibu menyusui dan penggunaan APD pada ibu menyusui. Adapun pelaksanaanya selama 3 hari pelaksanaan kegiatan yaitu pada tanggal 27 - 29 Juli 2020 oleh tim dosen pengabmas dan dibantu oleh tim pengabmas mahasiswa prodi D.III Kebidanan Manokwari dimana :

a) Pada Tanggal 27 Juli 2020

Sasaran terlebih dahulu diberitahukan mengenai kegiatan pelatihan ini sebelum kegiatan pengabdian masyarakat ini dilakukan. Sebelumnya melapor ke Puskesmas terkait ijin yang telah diberikan dan mempersiapkan tempat pelaksanaan kegiatan serta menginformasikan kepada bidan atau petugas imunisasi bahwa akan dilaksanakan kegiatan pengabdian dengan sasaran ibu menyusui.

b) Pada Tanggal 28 Juli 2020

Mempersiapkan tempat pelaksanaan kegiatan serta menginformasikan kepada bidan untuk mengikuti kegiatan program PKM. Setelah persiapan sarana, tempat dan materi telah dilakukan kemudian dilakukan briefing atau diskusi bersama bidan atau petugas imunisasi mengenai kegiatan pelaksanaan pengabmas dan menginformasikan pelaksanaan pengabmas selama 2 hari. Setelah melakukan diskusi kemudian tim pengabmas 
melakukan kontrak waktu menjelaskan sistematika pelaksanaan PKM sesuai protocol penanganan dan pencegahan Covid 19.

c) Pada Tanggal 29 Juli 2020

Sebelum dilakukannya ceramah atau penyuluhan penjelasan isi dari video atau pemberian video pada ibu menyusui, sebelumnya ibu menyusui diminta untuk mengisi kuisioner untuk mengetahui pengetahuan ibu menyusui tentang pencegahan covid 19 pada ibu menyusui dan penggunaan APD. Setelah ibu menyusui mengisi kuisioner pengetahuan kemudian pengabdi memberikan video pencegahan covid 19 pada ibu menyusui dan penggunaan APD pada ibu menyusui. Pengabdi menjelaskan kepada ibu menyusui bahwa video ini akan menjelaskan bagaimana ibu sebagai ibu menyusui melakukan pencegahan covid 19 saat menyusui dan saat dimana ibu dinyatakan status sebagai ODP (orang dalam pemnatauan) karena ibu perlu melindungi bayi ibu sebagai kelompok yang berisiko. Pengabdi mnejelaskan kepada ibu menyusui bahwa, ibu dapat menonton video ini selama 2 minggu atau 14 hari, kemudian setelah 14 hari pengabdi akan kembali mengevaluasi pengetahuan ibu tentang pencegahan covid 19 pada ibu menyusui dan penggunaan APD pada ibu menyusui. Saat pengabdi berinteraksi dengan ibu menyusui, pengabdi bersama tim yang dibantu mahasiswa menggunakan protokol kesehatan pencegahan covid 19 menggunakan APD lengkap. Setelah ibu dijelaskan mengenai isi video dan mengerti mengenai penjelasan oleh pengabdi, kemudian ibu menyusui diberikan masker, face shield dan hansanitaizer. Ibu menyusui juga diberikan form daftar hadir. Saat pelaksanaan pengabdian tanggal 28 Juli jumlah ibu yang menyusui hanya sebanyak 20 ibu yang setuju untuk dijadikan responden. Pengabdi juga memberikan masker dan face shield serta handsanitaizer ke pihak Puskesmas.

4. Evaluasi Kegiatan

Evaluasi yang dilakukan adalah dengan melakukan evaluasi setelah pemberian video yaitu :

a. Melakukan post test terhadap hasil kegiatan pengabmas pada sasaran dengan mengevaluasi pengetahuan ibu menyusui setelah 14 hari diberikan media video yang dapat ditunjukkan pada tabel dibawah ini:

Tabel 1.

Skor pengetahuan ibu menyusui sebelum dan setelah diberikan media videopencegahan covid 19 pada ibu menyusui dan penggunaan APD pada ibu menyusui

\begin{tabular}{cccc}
\hline No & Pengetahuan & $\mathbf{n}$ & $\begin{array}{c}\text { Skor Mean } \\
\text { pengetahuan }\end{array}$ \\
\hline 1 & Pre_test & 20 & 4,5 \\
2 & Post_test & 20 & 9,1 \\
\hline
\end{tabular}

Dari 20 ibu menyusui yang bersedia menjadi responden berdasarkan evaluasi yang telah dilakukan terjadi peningkatan pengetahuan ibu menyusui setelah diberikan penyuluhan menggunakan media video selama 14 hari, dimana terjadi peningkatan skor pengetahuan sebelum diberikan media video dengan rata-rata nilai pengetahuan 4,5 sedangkan setelah diberikan media video selama 14 hari terjadi peningkatan 
pengetahuan dengan nilai rata- rata pengetahuan 9,1 dari 10 pertanyaan yang diberikan. Evaluasi pengetahuan responden sebelum diberikan media video menggunakan kuisioner secara langsung yang diisi oleh responden sedangkan evaluasi pengetahuan setelah diberikan media video menggunakan kuisioner google form yang diisi secara online.

b. Melakukan observasi atau pengamatan terhadap pola kegiatan ibu menyusui dalam pencegahan covid 19 yaitu saat kembali berkunjung di Puskesmas saat kunjungan imunisasi dengan meminta bantuan bidan atau petugas imunisasi dengan menanyakan pola kegiatan menyusui ibu.

c. Melakukan follow up ke Wilayah Kerja Puskesmas Wosi untuk melihat apakah bentuk pengabdian masyarakat yang telah dilakukan dapat tetap diaplikasikan dalam kehidupan sehari-hari terutama pada ibu menyusui yang telah dapat secara mandiri melakukan pencegahan covid 19 secara benar baik dalam, proteksi diri, dan perubahan perilaku dimana diperoleh hasil follow up yaitu :

1) Media video tentang video pencegahan covid 19 pada ibu menyusui dan penggunaan APD pada ibu menyusui akan dijadikan sebagai media alat bantu di Puskesmas sebagai media promosi pencegahan covid 19 pada ibu menyusui dan penggunaan APD pada ibu menyusui.

2) Media video tentang video pencegahan covid 19 pada ibu menyusui dan penggunaan APD pada ibu menyusui akan diberikan saat kunjungan imunisasi berikutnya bulan depan.
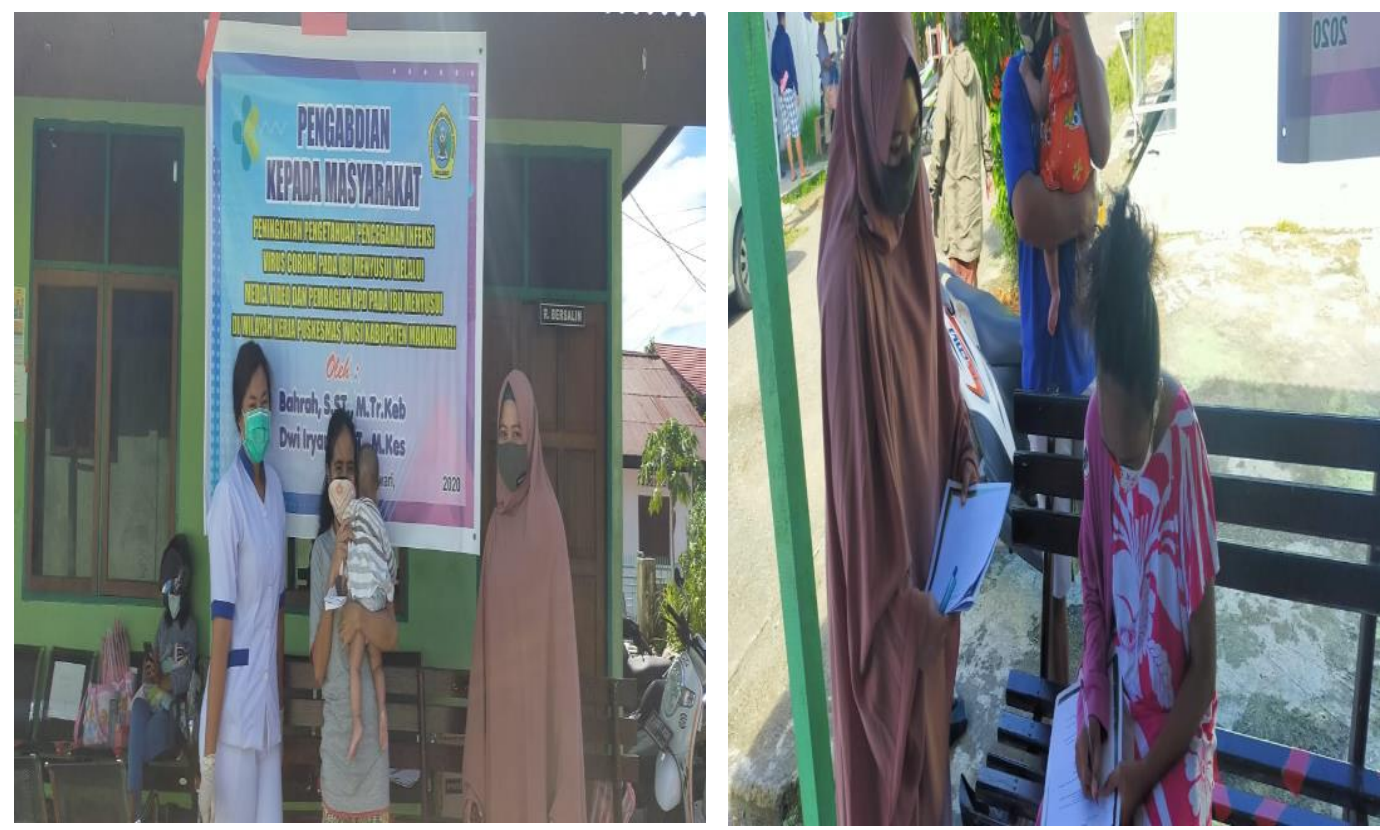

Gambar 3. Foto Pelaksanaan Kegiatan 

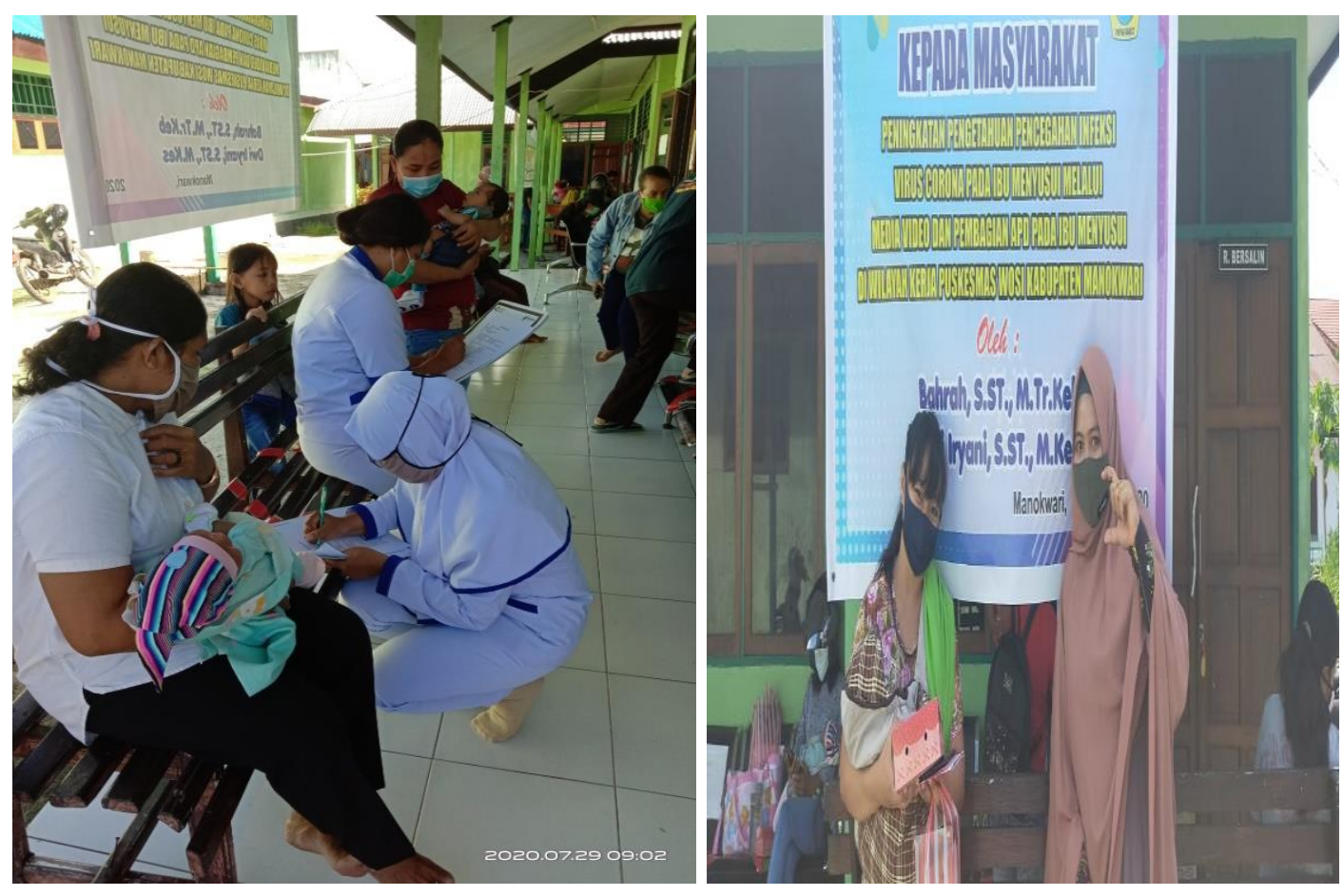

\section{Gambar 4. Foto Pelaksanaan Kegiatan PKM}

\section{b. Pembahasan}

Penyuluhan dalam pengabmas ini mengunakan media audio visual berupa video kesehatan tentang pencegahan covid 19 pada ibu menyusui. Materi dalam video lebih banyak menampilkan bentuk-bentuk pencegahan covid $19 \mathrm{pda}$ ibu menyusui, langkah cuci tangan yang benar dan penggunaan APD yang dibuat atau dikemas secara menarik sehingga responden tertarik untuk membacanya dan tidak bosan. Seperti yang diketahui bahwa masyarakat terkadang cenderung bosan apabila penyuluhan kurang menarik apalagi apabila penyuluhan dalam video tersebut membutuhkan waktu yang cukup lama untuk dibaca sehingga sudah tepat apabila video yang dibawakan dibuat dan dicari yang semenarik mungkin agar menarik perhatian responden. Video yang digunakan pada saat penyuluhan kesehatan dibuat dan dicari yang semenarik mungkin dengan mempertimbangkan minat responden yang cenderung lebih menyukai hal-hal baru dan unik serta adanya gambar yang menarik untuk menarik perhatian responden. Dalam menentukan media dan alat bantu penyuluhan kesehatan, peneliti mengacu pada pernyataan bahwa pengetahuan yang ada pada setiap manusia itu diterima atau ditangkap melalui panca indra. Semakin banyak indra yang digunakan untuk menerima sesuatu maka semakin banyak dan semakin jelas pengertian/ pengetahuan yang diperoleh (Hidayatullah, 2017)

Promosi kesehatan merupakan salah satu upaya yang dapat dilakukan untuk meningkatkan pengetahuan salah satunya melalui penyuluhan. Namun berhasilnya penyuluhan kesehatan tersebut pada masyarakat tergantung pada komponenn pembelajaran. Media penyuluhan kesehatan merupakan salah satu komponen dari proses pembelajaran. Media yang menarik akan memberikan 
keyakinan, sehingga perubahan kognitif afeksi dan psikomotor dapat dipercepat. Audiovisual merupakan salah satu media yang menyajikan informasi atau pesan secara audio dan visual (Hidayatullah, 2017).

Media penyuluhan dengan audio visual memberikan stimulus terhadap mata (penglihatan) dan telinga (pendengaran), sedangkan media cetak hanya menstimulasi indra mata (penglihatan). Mengingat pentingnya promosi kesehatan maka perlu adanya metode pembelajaran atau inovasi baru agar audiens bisa menerima pesan kesehatan dengan baik. Dalam penyuluhan kesehatan, banyak media yang digunakan untuk menunjang efektivitas penyuluhan kesehatan, media cetak seperti booklet, leaflet dan lain-lain merupakan media yang sering di gunakan, sedangkan media audio visual adalah media yang jarang digunakan dalam penyuluhan kesehatan maupun pembelajaran. Pemberian pengetahuan lebih menarik jika disampaikan dengan metode dan media yang menarik pula (Hidayatullah, 2017).

\section{KESIMPULAN}

a. Telah dilaksanakannya kegiatan pengabmas peningkatan pengetahuan pencegahan infeksi virus corona pada ibu menyusui melalui media Video dan Pembagian APD pada ibu menyusui di Wilayah Kerja Puskesmas Wosi Kabupaten Manokwari yang diperoleh jumlah ibu menyusui sebanyak 20 orang.

b. Adanya peningkatan skor pengetahuan sebelum diberikan media video dengan rata-rata nilai pengetahuan 4,5 sedangkan setelah diberikan media video selama 14 hari terjadi peningkatan pengetahuan dengan nilai ratarata pengetahuan 9,1 .

c. Hasil follow up media video tentang video pencegahan covid 19 pada ibu menyusui dan penggunaan APD pada ibu menyusui akan dijadikan sebagai media alat bantu di Puskesmas sebagai media promosi pencegahan covid 19 pada ibu menyusui dan penggunaan APD pada ibu menyusui.

d. Pelaksanaan pengabdian masyarakat peningkatan pengetahuan pencegahan infeksi virus corona pada ibu menyusui melalui media Video dan Pembagian APD pada ibu menyusui di Wilayah Kerja Puskesmas Wosi Kabupaten Manokwari dilaksanakan sesuai dengan jadwal kegiatan.

\section{DAFTAR PUSTAKA}

Bai Y, Yao L, Wei T, Tian F, Jin D-Y, Chen L, et al. (2020). Presumed Asymptomatic Carrier Transmission of COVID-19. JAMA. published online February 21. DOI: 10.1001/jama.2020.2565.

Chan JF-W, Kok K-H, Zhu Z, Chu H, To KK-W, Yuan S, et al. (2020). Genomic characterization of the 2019 novel human-pathogenic coronavirus isolated from a patient with atypical pneumonia after visiting Wuhan. Emerg Microbes Infect. 9(1):221-36.

Chen H, Guo J, Wang C, et al. (2020). Clinical characteristics and intrauterine vertical transmission potential of COVID-19 infection in nine pregnant women: a retrospective review of medical records. Lancet 2020;Available at: https: //doi.org/10.1016/S0140-6736(20)30360-3. 
Han Y, Yang H. (2020). The transmission and diagnosis of 2019 novel coronavirus infection disease (COVID-19): 2019. A Chinese perspective. J Med Virol. 2020; published online March 6. DOI: $10.1002 /$ jmv. 25749.

Hidayatullah, P., Dan, P., Kota, U., \& Tahun, K. (2017). No Title. 2(6), 1-11.

Jeratallah Aram Dani dan Yogi Mediantara (2020). Covid-19 Dan Perubahan Komunikasi Sosial. 2020. PERSEPSI: Communication Journal.

Kementerian Kesehatan Republik Indonesia (2020). Info Infeksi Emerging Kementerian Kesehatan RI [Internet]. 2020 [updated 2020 March 30; cited 2020 March 31]. Available from: https: // infeksiemerging.kemkes.go.id/.

Kementerian Kesehatan Republik Indonesia (2020). Pedoman Bagi Ibu Hamil, Bersalin, Nifas dan BBL, 2020. Jakarta. Direktorat Kesehatan Keluarga Direktorat Jenderal Kesehatan Masyarakat.

World Health Organization (2020). Coronavirus disease 2019 (COVID-19) Situation Report - 70 [Internet]. WHO; 2020 [updated 2020 March 30; cited 2020 March 31]. Available from: https://www.who.int/ docs/defaultsource/coronaviruse/situation-reports/20200330- sitrep-70-covid19.pdf?sfvrsn=7e0fe3f8_2

World Health Organization (2020). WHO Director-General's opening remarks at the media briefing on COVID-19 - 11 March 2020 [Internet]. 2020 [updated 2020 March 11]. Available from: https: / /www.who.int/dg/speeches/detail/who-director-generalsopening-remarks-at-the-media-briefing-on-covid-19---11- march-2020. 